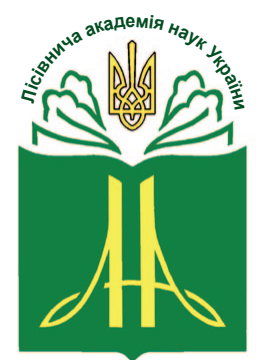

Forestry Academy of Sciences of Ukraine

Наукові праці Лісівничої академії наук України Proceedings of the Forestry Academy of Sciences of Ukraine

http://fasu.nltu.edu.ua

https://doi.org/10.15421/412025

Article received 2020.08.18

Article accepted 2020.12.28
ISSN 1991-606X print

ISSN 2616-5015 online

(a) $\triangle$ Correspondence author

Vasyl Yukhnovskyi

yukhnov@ukr.net

General Rodimtsev str., 19, Kyiv, 03041, Ukraine

УДК 630*164.3:582.475.2(23)

\title{
Особливості корененаселеності грунту в ялинових лісостанах у зоні гірської туристичної мережі
}

\author{
В.Ю. Юхновський ${ }^{1}$, Ю.С. Іваненко ${ }^{2}$, Г.О. Лобченко ${ }^{3}$
}

\begin{abstract}
Встановлено особливості корененаселеності грунту в ялинових лісостанах в умовах рекреаційного навантаження у зоні туристичних маршрутів Карпатського національного природного парку. На 13 пробних площах, закладених у чистих $і$ за невеликої участі бука лісового середньовікових і пристигаючих насадженнях, відібрано 136 зразків кореневмісного шару трунту на глибині 0-10, 10-20, 20-30 і 30-40 см, з яких виокремлено корені ялини європейської з розподілом їх на провідні і фізіологічно активні, обчислено об'єми і площі поверхні цих коренів. Встановлено статистичні зв'язки між висотою над рівнем моря та об' смом фракиії фізіологічно активних $i$ провідних коренів, коефічієнти корелячії яких становлять 0,78 і 0,47 відповідно. Розподіл коренів ялини європейської, залежно від глибини залягання материнської породи, показав, що у верхніх мінеральних шарах трунту за об 'ємом переважає фракиія провідного коріння. В деяких випадках його об'єм зростає з глибиною, що впливає на щільність поширення провідного коріння. За площею поверхні переважають фізіологічно активні корені на глибині 0-20 см, у той час, як на глибині 20-30 см спостережено перевагу провідного коріння. У грунтах із дещз потужнішими профілями у верхніх шарах (0-20 cм) та на глибині 30-40 см переважсає фракиія провідних коренів, але на глибині 20-30 см ия тенденція змінюється на користь фізіологічно активних. Основна частка коренів знаходиться у верхньому мінеральному шарі трунту на глибині до $10 \mathrm{cм}$, що й визначає їхню високу чутливість до рекреаиійних навантажень у гірських умовах. У иъому горизонті трунту частка провідних і фізіологічних коренів від загального об' 'му кожної фракиії становить 67,5 i 75,3\%, а в місчях із виходами гірських порід - 72,7 і 87,5\% відповідно.
\end{abstract}

Ключові слова: Карпатський наиіональний природний парк; ялина європейська; кореневі системи; провідні корені; фізіологічно активні корені.

Вступ. Вступаючи в нову епоху антропоцену, 3'являються якісно нові виклики щодо збереження довкілля. Діяльність людини та ії вплив на природні екосистеми характеризується докорінною зміною останніх. Ліс і всі його компоненти реагують на зміни навколишнього природного середо- вища, намагаючись пристосуватись до змін клімату та впливу людини. Проте механізм пластичності лісових екосистем не завжди може адекватно реагувати на такого роду навантаження. Починаючи 3 XIX ст., особливо активно розвивається промисловість, а з нею й емісія вуглецю в атмосферу, що сут-

1 Юхновський Василь Юрійович - академік Лісівничої академії наук України, доктор сільськогосподарських наук, професор кафедри відтворення лісів та лісових меліорацій. Національний університет біоресурсів і природокористування України, вул. Генерала Родимцева, 19, м. Київ, 03041, Україна. Тел.: +38-067-720-32-16. E-mail: yukhnov@ukr.net ORCID: http://orcid.org/0000-0003-3182-4347

2 Іваненко Юрій Сергійович - аспірант кафедри відтворення лісів та лісових меліорацій. Національний університет біоресурсів і природокористування України, вул. Генерала Родимцева, 19, м. Київ, 03041, Україна. Тел.: +38-063-870-88-10. E-mail: ura1408280594@gmail. com ORCID: https://orcid.org/0000-0002-3530-9206

3 Лобченко Ганна Олександрівна - кандидат сільськогосподарських наук, доцент кафедри відтворення лісів та лісових меліорацій. Національний університет біоресурсів і природокористування України, вул. Генерала Родимцева, 19, м. Київ, 03041, Україна. Тел.: +38-097-885-30-39. E-mail: lobchenko@nubip.edu.ua ORCID: https://orcid.org/0000-0001-9281-1107 
тєво впливає на процес глобального потепління в останні десятиліття. Відбувається помітне зростання інтенсивності екстремальних природних явищ (шторми, посухи, інтенсивні опади).

Поряд 3 цим, ліси продукують багато екосистемних послуг, які здатні пом'якшити вплив потепління. Зокрема, гірські екосистеми відіграють особливу роль у збереженні довкілля та середовища для рідкісних тварин, рослин і мікроорганізмів, тому такі території і відносять до об'єктів природнозаповідного фонду. Одним із таких об'єктів є Карпатський національний природний парк (Карпатський НПП), лісові екосистеми якого складають в основному ялина європейська, бук лісовий, ялиця біла, сосна гірська (Кравчинський, Мотрук, Стефурак, 2018). Лісостани за участю цих видів знаходяться під безпосереднім впливом як рекреаційного навантаження (парк має розгалужену мережу еколого-пізнавальних маршрутів), так і під впливом змін клімату (Крамарець, Мацях, 2018). Наприклад, ялина європейська формує поверхневу кореневу систему, є досить зимостійким та тіневитривалим деревним видом, проте досить чутлива до пізніх весняних приморозків (Іванюк, Фучило, 2020). Поряд 3 цим, ялина є досить вимогливою до вмісту вологи в повітрі та грунті.

Особливо чутливими до впливу клімату є чисті ялинові насадження (Дебринюк, 2011). За наявності вологи, підвищення температури повітря сприяє активізації кореневої губки у лісовій підстилці. Своєю чергою, збільшення тривалості вегетаційного періоду сприяє поширенню і розвитку осередків розмноження короїдів та інших стовбурових шкідників, що створює передумови для всихання ялинових лісостанів у гірських екосистемах (Лавний, Пелюх, 2019). До вищезазначених чинників додається і зелений туризм, популярність якого зростає 3 кожним роком. За концентрованого рекреаційного навантаження спостерігається негативний вплив на живе надгрунтове вкриття, особливо вздовж туристичних маршрутів.

Окрім рекреаційної дигресії, активізуються ерозійні процеси, змиваються верхні шари грунту, в яких безпосередньо знаходиться коренева система ялини (Брусак, Малець, 2018). Тому дослідження розповсюдження коренів ялини європейської в гірських екосистемах є важливим аспектом 3 погляду здійснення екологічної оцінки стану насаджень. Вивчення корененаселеності грунту під ялиновими деревостанами дає змогу з'ясувати вплив різних чинників на фракції коренів з метою розробки рекомендацій стосовно запровадження реконструктивних i фітомеліоративних заходів щодо відновлення стану насаджень уздовж екологічних стежок та їх адаптації до впливу кліматичних чинників. У гірських умовах потужність грунтових горизонтів незначна, що зумовлено особливостями рельєфу та близьким заляганням материнської породи (не враховуючи плато та деякі річкові долини). У таких умовах ялинові лісостани є дуже чутливими до негативного рекреаційного впливу та нестачі вологи в грунті.
Потрібно зазначити, що, окрім постачання, транспортування та нагромадження поживних речовин, самі кореневі системи, а саме, якірні корені, виконують важливу функцію утримання надземної частини дерева у вертикальному положенні та визначають стійкість дерев до впливу вітру. 3 меліоративного погляду, дослідження стану і розповсюдження коренів під ялинниками дає змогу систематизувати знання про їхню грунтоскріплювальну функцію у насадженнях, що $є$ особливо актуальним для гірської місцевості.

Кореневі системи є основним протиерозійним елементом лісового фітоценозу на схилових землях, де провідні (скелетні) корені забезпечують закріплення дерев у вертикальному положенні, а фізіологічно активні - забезпечують скріплення самого грунту, приймаючи участь у формуванні водотривких агрегатів, поліпшення водопроникності грунтів та активізації грунтотвірних процесів (Калінін, Гузь, Дебринюк, 1998).

Моделі поширення кореневих систем відіграють важливе значення в оцінці механічної стабільності надземної частини дерева та всього насадження. Особливо це стосується деревних видів, що мають поверхневу кореневу систему, до яких відноситься ялина європейська. Насадження ялини, особливо чисті за складом, що ростуть на багатих грунтах, дуже чутливі до негативного впливу вітру через особливості поширення їх кореневих систем. Проте мішані насадження ялини 3 буком мають кращу стійкість до вітру. Це пов'язано із особливостями поширення коріння бука, яке, розпушуючи грунт, дає можливість проникати кореням ялини на більшу глибину (Калинин, 1983).

Тип грунту також безпосередньо впливає на кількість кореневої біомаси, а також на іiі просторе розташування у розрізі грунтового профілю. Проте у мішаних ялино-букових насадженнях відбувається пригнічення як фізіологічно активних, так і провідних коренів ялини європейської буком лісовим (Schmid, 2002).

За даними ВО «Укрдержліспроект», станом на 1.01.2019 р. у межах природного ареалу (гірські ліси Карпат) площа лісостанів за перевагою ялини становить 414480,9 га із загальним запасом стовбурової деревини 149298,9 тис. м³. Запас самої стовбурової деревини ялини тут становить 126508,04 тис. ${ }^{3}$. Чисті ялинники в Українських Карпатах займають площу 164611,1 га, де вони нагромаджують 68465,2 тис. м ${ }^{3}$ стовбурової деревини.

Об'єкти та методика дослідження. Об' $\mathrm{\epsilon \kappa m}$ дослідження - чисті та мішані лісові насадження iз перевагою Picea abies [L.] Karst. у межах туристичної мережі Карпатського НПП та ДП «Гринявське ЛГ». Предмет дослідження - закономірності розподілу провідних і фізіологічно активних коренів ялини у грунтових горизонтах як протиерозійний чинник в умовах рекреаційного навантаження.

Meта дослідження полягала у встановленні співвідношення об'єму та площі поверхні для провідних і фізіологічно активних коренів ялини, як 
передумови протиерозійної стійкості ялинових фітоценозів в умовах рекреаційного навантаження.

Дослідження здійснювали в межах стежкової мережі трьох туристичних маршрутів - екологопізнавальних стежок «На гору Піп Іван» (Карпатський НПП), «с. Зелене - Угорські скелі» (ДП «Гринявське ЛГ») та «с. Зелене - г. Шкорушний» (Карпатський НПП). Досліджувані насадження вздовж цих маршрутів сформувалися на бурих гірськолісових та гірсько-підзолистих грунтах, ростуть на висотах від 1030 до 1510 м н.р.м. та на відстані від туристичних стежок до $100 \mathrm{M}$.

Для визначення лісівничо-таксаційних показників деревних видів у насадженнях закладено 13 кругових та напівкругових тимчасових пробних площ (ТПП) за загальноприйнятою у лісовій таксації і лісовпорядкуванні методикою (Лісотаксаиійний до- відник, 2013). Досліджувані насадження переважно чисті за складом, рідше - мішані із перевагою Picea adies та участю 1-2 од. у складі Fagus sylvatica L. або одиничних екземплярів роду Salix L. За віковою структурою переважають середньовікові і пристигаючі лісостани (табл. 1).

Існують різні методики оцінювання і встановлення корененаселеності грунту. Для оцінювання розташування провідних i фізіологічно активних коренів в окремих випадках використовують георадар, який дає змогу встановити поширення коріння у горизонтальному та вертикальному напрямах без фізичного втручання в кореневі системи. Перевагою цієї методики є можливість зберегти кореневу систему цілісною та здійснювати повторне оцінювання стану коренів у поверхневому шарі грунту (Borden, Thomas, \& Isaac, 2016).

Лісівничо-таксаційна характеристика ялинових фітоценозів

Таблиия 1

\begin{tabular}{|c|c|c|c|c|c|c|c|c|}
\hline $\begin{array}{c}\text { № } \\
\text { ТПП }\end{array}$ & $\begin{array}{c}\text { Висота над } \\
\text { рівнем моря, м }\end{array}$ & $\begin{array}{l}\text { Стрімкість } \\
\text { схилу, град. }\end{array}$ & $\begin{array}{c}\text { Експозиція } \\
\text { схилу }\end{array}$ & $\begin{array}{l}\text { Вік, } \\
\text { років }\end{array}$ & $\begin{array}{c}\text { Склад } \\
\text { насадження }\end{array}$ & Бонітет & $\begin{array}{c}\text { Висота, } \\
\text { м }\end{array}$ & $\begin{array}{l}\text { Діаметр, } \\
\text { см }\end{array}$ \\
\hline
\end{tabular}

Туристичний маршрут «с. Зелене - г. Шкорушний»

\begin{tabular}{ccccccccc}
\hline 1 & 1385 & 23 & Пд-3х & 66 & 10 Ялє & I $^{\text {b }}$ & 28,0 & 34,9 \\
2 & 1317 & 15 & Пд-Сх & 65 & 10 Ялє & I & 24,0 & 28,1 \\
\hline
\end{tabular}

Туристичний маршрут «Еколого-пізнавальна стежка «На гору Піп Іван»

\begin{tabular}{|c|c|c|c|c|c|c|c|c|}
\hline 3 & 1260 & 11 & $\mathrm{Cx}$ & 50 & 10Ялє & $\mathrm{I}^{\mathrm{b}}$ & 24,0 & 22,7 \\
\hline 4 & 1510 & 13 & Пн-Сх & 59 & 10Ялє & III & 16,9 & 23,3 \\
\hline 5 & 1030 & 18 & Пд & 58 & 10Ялє & $\mathrm{I}^{\mathrm{b}}$ & 29,3 & 31,5 \\
\hline 6 & 1040 & 19 & Пд-Сх & 63 & 10Ялє & $\mathrm{I}^{\mathrm{c}}$ & 32,3 & 31,8 \\
\hline 7 & 1070 & 9 & Пд-3x & 79 & 10Ялє & $\mathrm{I}^{\mathrm{a}}$ & 30,4 & 32,3 \\
\hline 8 & 1070 & 8 & Пд-Сx & 75 & 9Ялє1Бк & $\mathrm{I}^{\mathrm{b}}$ & 31,7 & 35,5 \\
\hline 9 & 1280 & 4 & Пд & 50 & 10Ялє + Врб & $\mathrm{I}^{\mathrm{a}}$ & 22,0 & 20,5 \\
\hline 10 & 1305 & 21 & Пд & 34 & 10Ялє & $\mathrm{I}^{\mathrm{c}}$ & 19,9 & 24,4 \\
\hline \multicolumn{9}{|c|}{ Туристичний маршрут «с. Зелене - Угорські скелі» } \\
\hline 11 & 1040 & 8 & Пн-Cx & 62 & 9Ялє1Бк & $\mathrm{I}^{\mathrm{a}}$ & 24,9 & 26,7 \\
\hline 12 & 1090 & $<2$ & Пн-Cx & 67 & 9Ялє1Бк & $\mathrm{I}^{\mathrm{a}}$ & 26,4 & 28,3 \\
\hline 13 & 1095 & $<2$ & Пд-3x & 48 & 8Ялє2Бк & $\mathrm{I}^{\mathrm{b}}$ & 25,4 & 32,4 \\
\hline
\end{tabular}

Фізіологічно активні корені є одним із найвагоміших компонентів підземної частини дерева. Ці корені характеризуються високою пластичністю, чутливо реагуючи на зміни в грунті та постачання води і поживних речовин (Püttsepp, Lõhmus, Persson, \& Ahlström, 2006). У насадженнях на кожній тимчасовій пробній площі за показником середнього діаметра вибирали модельне дерево, поблизу якого на відстані 0,5-1 м спеціальним буром відби- рали зразки кореневмісного шару грунту на глибині 0-10, 10-20, 20-30 і 30-40 см у взаємно перпендикулярних напрямах (рис. 1). У загальному підсумку відібрано 136 зразків.

Зі зразків кореневмісного шару грунту виокремлено корені ялини європейської та розділено на дві фракції: провідне (діаметром $>2$ мм) і фізіологічно активне (діаметром $<2$ мм). Діаметри коренів вимірювали мікрометром та встановлювали серед- 
нє значення показника діаметра для кожної фракції. Об'єм відібраного коріння визначали ксилометричним методом. Площі поверхні кореневої системи за фракціями розраховували за методами і методиками вивчення кореневих систем деревних рослин (Калинин, 1983; Дебринюк, 1990; Калінін, Гузь, Дебринюк, 1998; Маурер та ін., 2019).

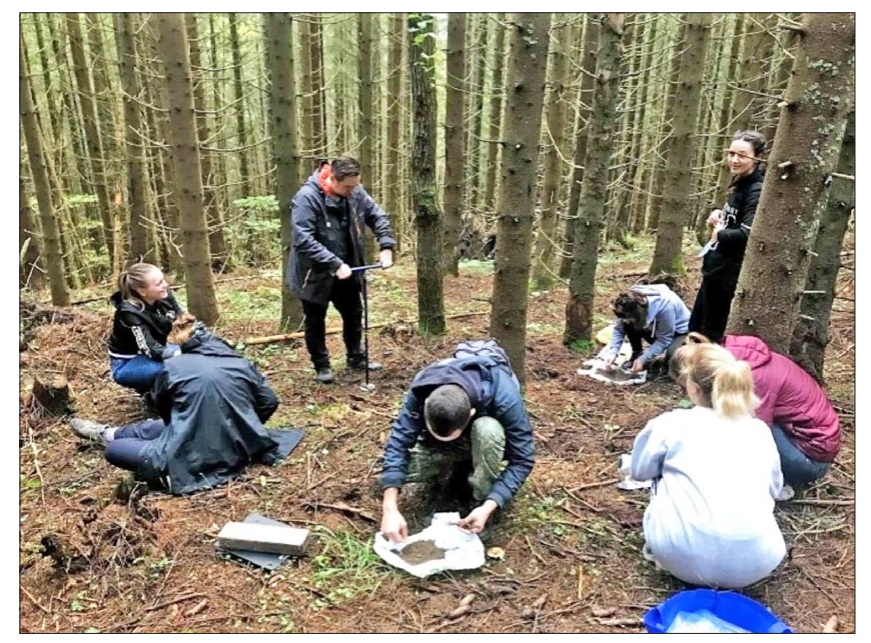

Рис. 1. Фрагмент відбору зразків кореневмісного шару грунту та їх опрацювання на пробній площі № 9 (N 48 00.961', E $024^{\circ} 39.636^{\prime}$ ') на території Карпатського НПП. Склад насадження - 10Ялє, вік -50 років

Результати та обговорення. Кореляційний аналіз орографічних показників та об'ємів коренів за фракціями вказує, що існує статистично значущий зв'язок між висотою над рівнем моря та об'ємом фракції фізіологічних коренів, однак для фракції провідних коренів такий зв'язок слабший. Також встановлено незначний статистичний зв'язок між стрімкістю схилів та об'ємами коренів у відібраних зразках кореневмісного шару грунту (табл. 2).

Функціональний тип рослин і клімат є найсильнішими предикторами мінливості будови кореневих систем, і як наслідок - корененаселеності грунту, особливо фракції фізіологічно активних коренів (Freschet et al., 2017). У цьому аспекті методи оцінювання поширення кореневих систем та розробки методики відбору зразків активно розвивались в XX ст. (Schuurman \& Goedewaagen, 1971). Міжвидове порівняння кореневих систем хвойних $\mathrm{i}$ широколистяних деревних видів на прикладі псевдотсуги Мензіса та бука лісового в гірських екосистемах Болгарії показало більшу відмінність у поширенні коренів за грунтовими горизонтами, ніж у динаміці росту фізіологічних коренів впродовж року. Так, наприклад, маса коренів завтовшки $<10$ мм в діаметрі на глибині 0-45 см була значно вищою у бука, порівняно $з$ дугласією. Корені хвойної породи знаходилось переважно у верхньому мінеральному шарі грунту. Їхня кількість дуже різко зменшувалась 3 глибиною на відміну від коренів бука, де поширення коренів у глибину було рівномірнішим (Lozanova et al., 2019).
Таблиия 2

Кореляційна матриця орографічних показників і об'єму коренів

\begin{tabular}{|c|c|c|c|c|}
\hline 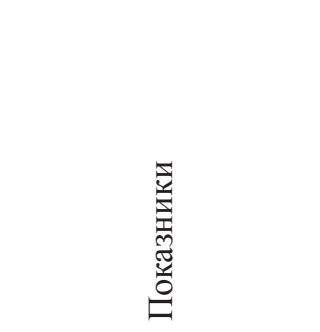 & 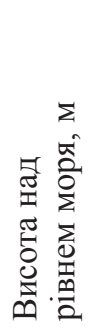 & 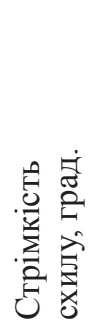 & 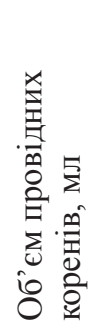 & 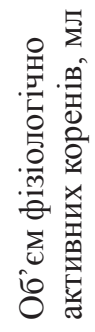 \\
\hline $\begin{array}{l}\text { Висота над рівнем } \\
\text { моря, м }\end{array}$ & 1,00 & & & \\
\hline $\begin{array}{l}\text { Стрімкість схилу, } \\
\text { град. }\end{array}$ & 0,33 & 1,00 & & \\
\hline $\begin{array}{l}\text { Об'єм провідних } \\
\text { коренів, мл }\end{array}$ & 0,47 & $-0,19$ & 1,00 & \\
\hline $\begin{array}{l}\text { Об’єм фізіологічно } \\
\text { активних коренів, мл }\end{array}$ & 0,78 & 0,07 & 0,73 & 1,00 \\
\hline
\end{tabular}

Однак, для досліджених ялинових насаджень, за даними кореляційної матриці (табл. 3) наявність у складі кількох одиниць бука не має зв'язку із розподілом фракцій коренів. Відсутній також статистично значущий зв'язок між показниками об'єму й площі поверхні коренів та віком. У той же час встановлено зв'язок між середньою висотою деревостану, абсолютною повнотою та запасом.

Як відомо, основну роль у поглинанні поживних речовин підземною частиною дерева відіграє фізіологічно активне коріння. Спостерігається природна конкуренція між кореневими системами як у чистих, так і в мішаних насадженнях. Щільніше переплітання кореневих систем спостерігається на багатих на поживні речовини грунтах. Проте існує думка, що висока щільність корененаселеності грунту зумовлена лімітом води та обмеженістю доступу коренів до поживних речовин. Пластичність фізіологічних коренів, його біомаса та щільність розташування вказують на рівень здатності до конкуренції за середовище існування (Schmid \& Kazda, 2002).

Важливим показником залучення коренів до підвищення протиерозійної стійкості території $\epsilon$ їхній об'єм і площа поверхні, що взаємодіє із грунтовим середовищем, які узагальнено на графіках у розрізі глибини відбору зразків кореневмісного шару грунту (рис. 2, 3).

Вертикальний розподіл кореневих систем деревних порід визначає їхній потенціал щодо абсорбування поживних речовин із різних грунтових горизонтів. Здатність коренів різних фракцій проникати в різні горизонти у пошуках поживних речовин $є$ одним із ключових чинників, що визначають ріст і продуктивність надземної частини деревних 
видів (Li et al., 2020). Фізіологічно активне коріння підліску та його розповсюдження безпосередньо впливає на продуктивність всієї екосистеми (Finér, Ohashi, Noguchi, \& Hirano, 2011). Фізичні властивості грунтів, наявність води та поживних речовин визначають стратегію екологічного розвитку рос- лин (Ding et al., 2020). Тобто, дерева 3 поверхневим розповсюдженням кореневих систем в умовах недостатнього вмісту вологи у верхніх шарах грунту можуть поширювати своє коріння на більшу глибину (Freschet, Violle, Bourget, Scherer-Lorenzen, \& Fort, 2018).

\section{Кореляційна матриця таксаційних показників і коренів}

Таблиия 3

\begin{tabular}{|c|c|c|c|c|c|c|c|c|c|c|}
\hline Показники & $\begin{array}{c}\mathrm{A}, \\
\text { років }\end{array}$ & Склад & $\begin{array}{c}\mathrm{H}, \\
\mathrm{M}\end{array}$ & $\begin{array}{l}\mathrm{D}, \\
\mathrm{cm}\end{array}$ & $\begin{array}{c}\mathrm{G}, \\
\mathrm{M}^{2} \cdot \mathrm{\Gamma a}^{-1}\end{array}$ & $\begin{array}{c}\mathrm{M}, \\
\mathrm{M}^{3} \cdot \mathrm{\Gamma a}^{-1}\end{array}$ & $\begin{array}{l}\mathrm{V}_{\text {пр. }} \\
\text { МЛ }\end{array}$ & $\begin{array}{l}\mathrm{V}_{\text {фз. }}, \\
\text { мл }\end{array}$ & $\begin{array}{c}\mathrm{S}_{\text {пр. }}, \\
\text { мЛ }\end{array}$ & $\begin{array}{c}\mathrm{S}_{\text {фз. }}, \\
\text { МЛ }\end{array}$ \\
\hline А, років & 1,00 & & & & & & & & & \\
\hline Склад насадження & $-0,02$ & 1,00 & & & & & & & & \\
\hline $\mathrm{H}_{\text {cep }}, \mathrm{M}$ & 0,64 & $-0,14$ & 1,00 & & & & & & & \\
\hline $\mathrm{D}_{\mathrm{cep}}, \mathrm{cm}$ & 0,59 & $-0,32$ & 0,81 & 1,00 & & & & & & \\
\hline $\mathrm{G}, \mathrm{M}^{2} \cdot \mathrm{ra}^{-1}$ & 0,38 & $-0,28$ & 0,35 & 0,14 & 1,00 & & & & & \\
\hline $\mathrm{M}, \mathrm{M}^{3} \cdot \mathrm{ra}^{-1}$ & 0,48 & $-0,13$ & 0,61 & 0,15 & 0,59 & 1,00 & & & & \\
\hline $\mathrm{V}_{\text {np. }}$ & $-0,05$ & $-0,12$ & $-0,66$ & $-0,40$ & $-0,35$ & $-0,46$ & 1,00 & & & \\
\hline $\mathrm{V}_{\text {фз. }}$ & $-0,02$ & 0,18 & $-0,60$ & $-0,29$ & $-0,40$ & $-0,66$ & 0,73 & 1,00 & & \\
\hline $\mathrm{S}_{\text {пв. }}$ & $-0,10$ & 0,02 & $-0,60$ & $-0,21$ & $-0,54$ & $-0,68$ & 0,82 & 0,78 & 1,00 & \\
\hline $\mathrm{S}_{\phi з .}$ & $-0,01$ & 0,14 & $-0,52$ & $-0,16$ & $-0,42$ & $-0,65$ & 0,61 & 0,94 & 0,70 & 1,00 \\
\hline
\end{tabular}

Примітки. А - вік деревостану, Н - середня висота деревостану, D - середній діаметр деревостану, $\mathrm{G}$ - абсолютна повнота, $\mathrm{M}$ - запас, $\mathrm{V}_{\text {пр. }}$ - об’єм провідних коренів; $\mathrm{V}_{\phi з .}-$ об'єм фізіологічно активних коренів, $\mathrm{S}_{\text {пр. }}$ - площа поверхні провідних коренів, $\mathrm{S}_{\phi з .}-$ площа поверхні фізіологічно активних коренів
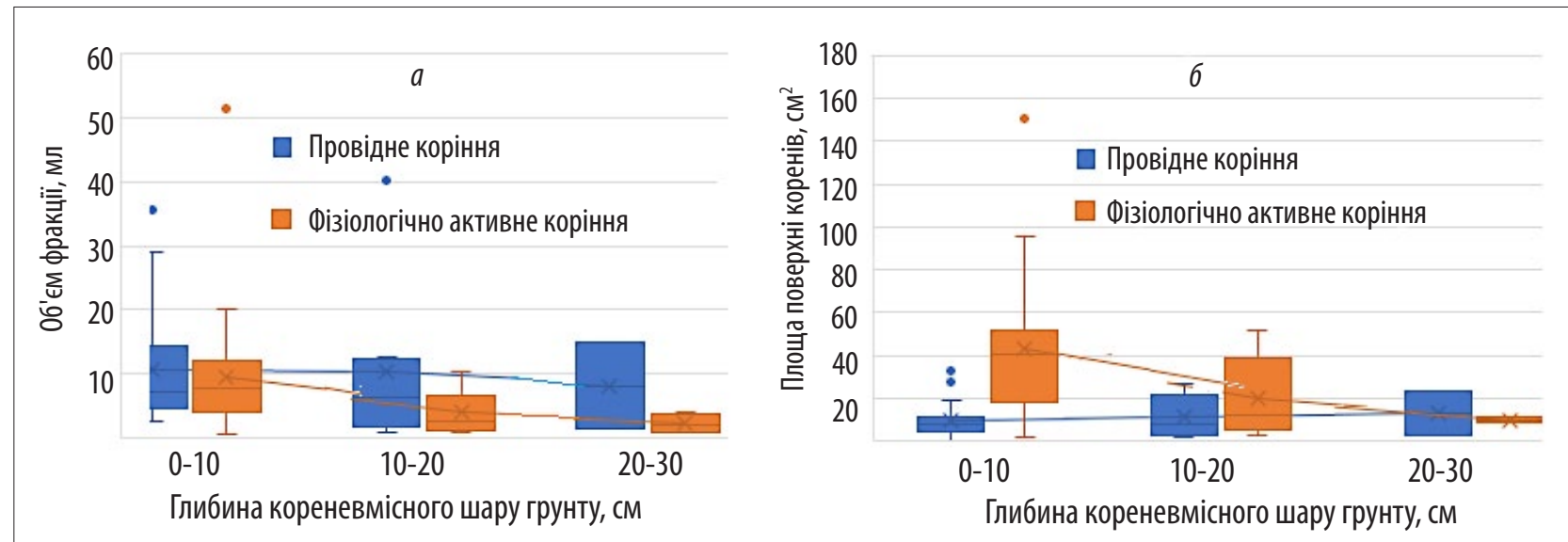

Рис. 2. Поширення фракцій коренів ялини європейської за умов близького залягання материнської породи: а) за об’ємами фракцій, мл; б) за площею поверхні, см²

Враховуючи, що на розподіл кореневих систем ялини європейської у лісових фітоценозах впливає глибина залягання материнської породи, тимчасові пробні площі поділено на дві категорії: 1) із заляганням материнської породи на глибині до $30 \mathrm{~cm}$ (ТПП № $1,4,5,6,7,8,10)$; 2) із заляганням материнської породи на глибині понад 30 см (ТПП №2, $3,9,11,10,13)$.

Висота над рівнем моря для тимчасових пробних площ першої категорії змінюється від 1040 до
1510 м. Насадження представлені переважно чистими ялиновими деревостанами. Квантилі коробкових графіків (див. рис. 2) містять в собі дані про значення медіани, середньоарифметичної вибірки на різних глибинах. Вуса діаграм вказують на найнижче та найвище значення даних у межах 1,5 IQR (міжквартильного інтервалу) вище верхнього та нижнього квартилів. У верхніх мінеральних шарах грунту за об'ємом переважає фракція провідних коренів, наявність якої з глибиною, в цьому конкрет- 
ному випадку, збільшується, тобто зростає щільність населеності корінням грунту. За площами поверхні переважають фізіологічно активні корені на глибині 0-20 см, у той час, як на глибині 20-30 см спостережено перевагу провідних коренів. Загалом варто зазначити, що розподіл об'єму коренів з глибиною не $є$ пропорційним розподілу площі їхньої поверхні.

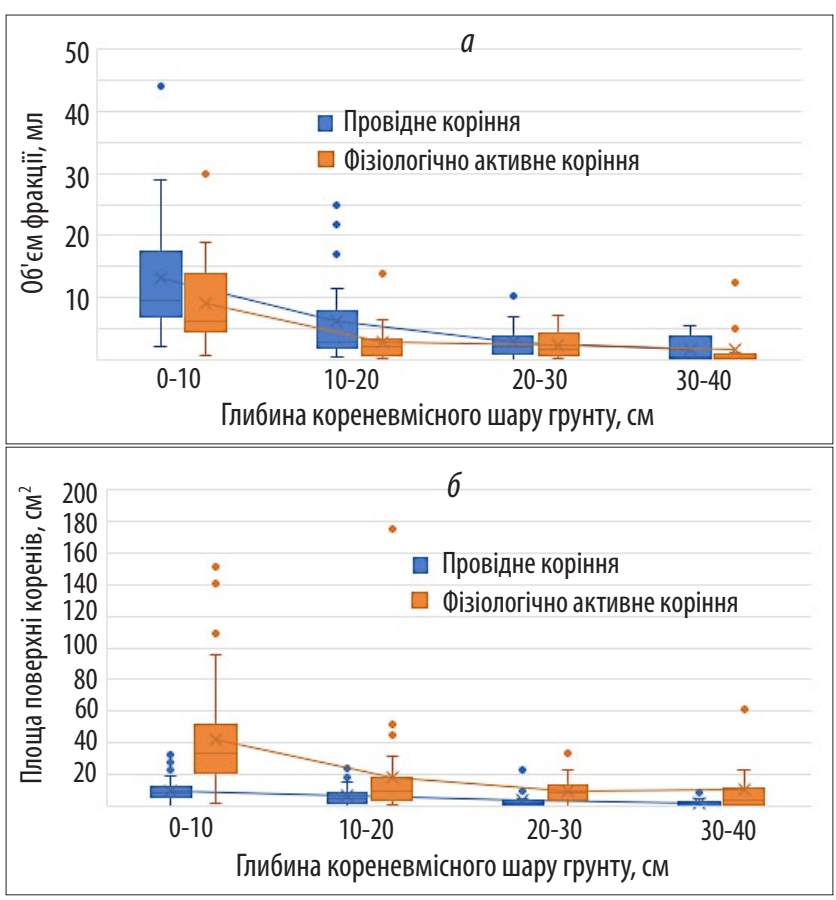

Рис. 3. Поширення фракцій коренів ялини європейської за умов залягання материнської породи на глибині понад 30 см: а) за об'ємами фракцій, мл; б) за площею поверхні, $\mathrm{cm}^{2}$

Для іншої категорії насаджень 3 потужнішим грунтовим профілем відбір зразків на глибину понад 40 см не здійснювали, що пов'язано з морфологічними особливостями кореневої системи ялини. За об'ємом у верхніх шарах (0-20 см) та на глибині 30-40 см переважає фракція провідних коренів, хоча на глибині 20-30 см ця тенденція зміню- ється на користь фізіологічно активних коренів, що й ілюструє рис. 3 .

Зворотну тенденцію спостережено для показника площі поверхонь фракцій коренів на відповідних ТПП. Перевага фізіологічно активних коренів представлена на всіх зазначених глибинах кореневмісного шару грунту. Незважаючи на відсутність пропорційності між об'ємами та площами коренів, спостережено тенденцію до зменшення об'єму і площі поверхні коренів із збільшенням глибини.

Для обох виокремлених категорій об'єктів дослідження присутні викиди, які знаходяться поза межами міжквартильного інтервалу 1,5 IQR, що є характерним як для об'ємів коренів, так і для їхніх площ. Варто зазначити, що статистичні викиди серед зразків, які були відібрані з глибини 0-40 см, трапляються частіше і можуть бути зумовлені помилками у вимірюванні або ж пояснюватись умовами об'єкту досліджень. Так, для досліджуваних насаджень характерною є висока повнота, що безпосередньо впливає на щільність переплітання кореневих систем двох і більше рослин одного виду, що, своєю чергою, призводить до неможливості виокремлення коренів одного екземпляру ялини від іншого. 3 іншого боку, складність рельєфу та наявність кам'янистих включень і виступів материнської породи у різних горизонтах також має безпосередній вплив на розподіл та кількість коренів у товщі грунту. Враховуючи поверхневий характер кореневих систем, ялина намагається зайняти максимально вигідну «нішу» в грунтовому середовищі, враховуючи при цьому виступи материнської породи та корені інших рослин.

Також встановлено, що основна маса коренів, не прив'язуючись до потужності грунтового профілю, знаходиться у верхніх мінеральних шарах на глибині до 10 см (табл. 4). Така особливість зумовлена сприятливими фізико-хімічними властивостями, що забезпечують необхідний ступінь аерації та зволоження від атмосферних опадів і наявністю легкодоступних для рослинного організму поживних речовин (Маурер та ін., 2019).

Таблиияя 4

Поширення коренів ялини свропейської у верхньому шарі грунту

\begin{tabular}{|c|c|c|c|c|c|c|}
\hline $\begin{array}{c}\text { Номер } \\
\text { ТПП }\end{array}$ & $\begin{array}{c}\text { Об’єм провідних } \\
\text { коренів у 10-см } \\
\text { шарі грунту, мл }\end{array}$ & $\begin{array}{c}\text { Загальний } \\
\text { об'єм } \\
\text { провідних } \\
\text { коренів, мл }\end{array}$ & $\begin{array}{c}\text { Частка провідних } \\
\text { коренів у 10-см } \\
\text { шарі грунту, \% }\end{array}$ & $\begin{array}{c}\text { Об’єм фізіологічно } \\
\text { активних коренів } \\
\text { у 10-см шарі } \\
\text { грунту, мл }\end{array}$ & $\begin{array}{c}\text { Загальний об’єм } \\
\text { фізіологічно } \\
\text { активних } \\
\text { коренів, мл }\end{array}$ & $\begin{array}{c}\text { Частка } \\
\text { фізіологічно } \\
\text { активних коренів } \\
\text { у 10-см шарі } \\
\text { грунту, \% }\end{array}$ \\
\hline 1 & 2 & 3 & 4 & 5 & 6 & 7 \\
\hline 1 & 36,4 & 61,7 & 59,0 & 54,0 & 72,8 & 74,2 \\
\hline 2 & 36,65 & 85,9 & 42,7 & 65,8 & 118,7 & 55,5 \\
\hline 3 & 31,2 & 57,5 & 54,3 & 26,05 & 65,9 & 39,6 \\
\hline 4 & 192,68 & 192,7 & 100,0 & 158,2 & 160,2 & 98,8 \\
\hline 5 & 24,0 & 24,0 & 100,0 & 20,8 & 20,8 & 100,0 \\
\hline
\end{tabular}


Продовж. табл. 4

\begin{tabular}{ccccccc}
\hline 1 & 2 & 3 & 4 & 5 & 6 & 7 \\
\hline 6 & 45,9 & 45,9 & 100,0 & 27,8 & 27,8 & 100,0 \\
7 & 25,7 & 65,8 & 39,1 & 42,0 & 44,7 & 94,0 \\
8 & 12,6 & 25,3 & 49,8 & 16,0 & 26,2 & 61,1 \\
9 & 34,4 & 62,1 & 55,4 & 24,5 & 46,4 & 52,8 \\
10 & 32,2 & 52,8 & 61,0 & 26,4 & 31,2 & 84,6 \\
11 & 104,2 & 133,4 & 78,1 & 22,7 & 32,0 & 70,9 \\
12 & 59,9 & 68,2 & 87,8 & 23,8 & 33,5 & 71,0 \\
13 & 48,0 & 94,7 & 50,7 & 53,1 & 69,9 & 76,0 \\
\hline
\end{tabular}

У середньому, на досліджуваних ділянках у верхньому 10-сантиметровому шарі грунту частка провідних коренів за об'ємом становить 67,5\% від загального об'єму коренів фракції, а для фізіологічно активних коренів - відповідно 75,3\%. Якщо взяти до уваги зразки із пробних площ, де поширення кореневих систем обмежене близьким заляганням гірської породи, то для таких насаджень частка у 10-сантиметровому кореневмісному шарі для провідних коренів становить 72,7, а фізіологічно активних $-87,5 \%$.

Висновки. Встановлено тісний i середній зв'язок між гіпсометричною висотою та об'ємом фракції фізіологічно активних і провідних коренів, коефіцієнти кореляції яких становлять 0,78 і 0,47 відповідно.

Статистичний зв'язок показників розподілу коренів встановлено для середньої висоти деревостану, абсолютної повноти та запасу, а між віком та складом насадження статистично значущого зв' язку не виявлено.

На об'єктах природо-заповідного фонду основна частка коренів знаходиться у верхньому мінеральному шарі грунту на глибині до 10 см. Таке мілке розташування коренів зумовлює дуже високу чутливість ялини до рекреаційних навантажень у гірських умовах. Неглибоке розміщення коренів зумовлене сприятливими фізико-хімічними властивостями верхнього шару грунту, що забезпечує необхідний ступінь аерації та зволоження від атмосферних опадів i наявність легкодоступних для деревної рослини поживних речовин.

3 цього погляду, особливу увагу щодо біотичної стійкості необхідно приділяти ялиновим лісостанам, що ростуть в умовах близького залягання материнської породи. Частка об'єму провідних і фізіологічно активних коренів від загального обсягу, в цьому шарі становить 67,5 і 75,3\% відповідно, а в місцях із виходами гірських порід - 72,7 i $87,5 \%$.

\section{Список літератури}

Брусак В.П., Малець В.Б. (2018). Рекреаційна дигресія на туристичному маршруті. «На гору Говерла» у Карпатському НПП. Природні ресурси регіону: проблеми використання, ревіталізації та охорони: матеріали III міжнарод. наук. семінару, 58-63. м. Львів [Brusak, V.P., \& Malets, V.B. (2018). Recreational digression on tourist routes «On Hoverla mount» in Carpathian National Nature Park. In Natural resources of the region: problems of use, revitalization and protection. Materials of the 3rd scientific seminar, 58-63. Lviv, Ukraine (in Ukrainian)]

Дебринюк, Ю.М. (1990). О корненаселенности почвы в смешанных насаждениях дуба черешчатого и ели обыкновенной. Лесной журнал, 6 , 13-16. [Debryniuk, Yu. M. (1990). On the root population of the soil in mixed plantations of pedunculate oak and common spruce. Forest Journal, 6, 13-16 (in Russian)]

Дебринюк Ю. М. (2011). Всихання смерекових лісів: причини та наслідки. Науковий вісник НЛТУ України «Урбанізачійні прочеси в гірських ландшафтах і шляхи їхнього регулювання», 21.16, 3238 [Debryniuk, Yu. M. (2011). Drying of spruce forests: causes and consequences. Scientific bulletin of the Ukrainian National Forestry University: Urbanization processes in mountain landscapes and ways of regulation, 21 (16), 32-38 (in Ukrainian)]. Retrieved from http://nltu.edu. ua/nv/Archive/2011/21_16/index21_16.htm

Голубець, М.А. (1978). Ельники Украинских Kapnam. Киев: Наукова думка [Golubets, М.A. (1978). Spruce forests of the Ukrainian Carpathians. Kyiv: Scientific thought (in Russian)]

Іванюк І.Д., Фучило Я.Д. (2020). Вплив метеорологічних чинників на радіальний приріст дуба звичайного в умовах свіжих і вологих сугрудів Полісся України. Наукові пращі Лісівничої академї наук України, 20, 57-63. [Ivanyuk, I., \& Fuchylo, Y. (2020). Influence of meteorological factors on the radial increase of English oak trees in the fresh and moist fairly fertile forest types conditions of the Ukrainian Polissya. Proceedings of the Forestry Academy of 
Sciences of Ukraine, 20, 57-63 (in Ukrainian)]. https:// doi.org/10.15421/412005

Калінін, М. І., Гузь, М. М., Дебринюк, Ю. М. (1998). Лісове коренезнавство. Львів: Престиж-інформ [Kalinin, M. I., Guz, M. M., \& Debryniuk, Yu. M. (1998). Forest root science. Lviv: Prestige-inform (in Ukrainian)]

Калинин, М.И. (1983). Формирование корневой системь деревьев. Москва: Лесная промышленность [Kalinin, M.I. (1983). Formation of the root system of trees. Moscow: Timber industry (in Russian)]

Карпатський національний природний парк. [Carpathian National Nature Park (in Ukrainian)]. Retrieved from http://cnnp.if.ua/

Крамарець В. О., Мацях І.П. (2018). Роль біотичних чинників у всиханні ялинників Українських Карпат. Наукові прачі Лісівничої академії наук України, 17, 121-132 [Kramarets, V., \& Matsiakh, I. (2018). The role of biotic factors in spruce decline in the Ukrainian Carpathians. Proceedings of the Forestry Academy of Sciences of Ukraine, 17, 121-132 (in Ukrainian)]. https:// doi.org/10.15421/411827

Кравчинський Р.Л., Мотрук М.В., Стефурак О.М. (2018). Причини послаблення біотичної стійкості ялинників на території Карпатського НПП. $\mathrm{Cbo}$ годення біологічної науки: матеріали міжнарод. наук. конф., 22-24. м. Суми [Kravchynskyi, R.L., Motruk, M. V., \& Stefurak, O.M. (2018). The reasons for the weakening of the biotic stability of spruce trees in the Carpathian National Park. In Today's of the biological science, 22-24. Sumy, Ukraine (in Ukrainian)]

Лавний В.В., Пелюх О.Р. (2019). Поширення та аналіз стану похідних ялинових деревостанів в Українських Карпатах. Наукові праці Лісівничої академії наук України, 19, 60-67 [Lavnyi, V., \& Pelukh, O. (2019). Distribution and analysis of the state of secondary spruce stands in the Ukrainian Carpathians. Proceedings of the Forestry Academy of Sciences of Ukraine, 19, 60-67 (in Ukrainian)]. https://doi. org/10.15421/411927

Лісотаксаційний довідник (2013). Затвердж. Держ. агентством лісових ресурсів України / за ред. С. М. Кашпора, А. А. Строчинського. Київ: Видавничий дім «Вініченко» [Forest Inventory Directory (2013): approved by the State Agency of Forest Resources of Ukraine. In S. Kashpor, A. Strochinskyi (Eds.). Kyiv: Vinichenko Publishing House (in Ukrainian)]

Маурер В.М., Атаманюк В.Ю., Белеля С.О., Бобошко-Бардин ..М., .. Яцик Р. М. (2019). Відтворення лісів та лісова меліорація в Україні: витоки, сучасний стан, виклики сьогодення та перспективи в умовах антропоцену: монографія. Київ: РВД НУБіП України [Maurer, V., Atamaniuk, V., Belelia, S., Blystiv, V., Boboshko-Bardyn, I., Boiko, O.,... Yatsyk, R. (2019). Forest restoration and forest melioration in Ukraine: beginning, current state, challenges of the present and prospects in the conditions of the anthropocene. Kyiv: National University of Life and Environmental sciences of Ukraine (in Ukrainian)]
Borden, K.A., Thomas, S.C., \& Isaac, M.E. (2016). Interspecific variation of tree root architecture in a temperate agroforestry system characterized using ground-penetrating radar. Plant and Soil, 410 (1-2), 323-334. https://doi:10.1007/s11104-016-3015-x

Ding, J., Kong, D., Zhang, Z., Cai, Q., Xiao, J., Liu, Q., \& Yin, H. (2020) Climate and soil nutrients differentially drive multidimensional fine root traits in ectomycorrhizal-dominated alpine coniferous forests. Journal of Ecology, 108 (6), 2544-2556. https://doi.org/10.1111/1365-2745.13407

Finér, L., Ohashi, M., Noguchi, K., \& Hirano, Y. (2011) Factors causing variation in fine root biomass in forest ecosystems. Forest Ecology and Management, 261, 265-277. https://doi.org/10.1016/j.foreco.2010. 10.016

Freschet, G. T., Valverde-Barrantes, O. J., Tucker, C.M., Craine, J.M., McCormack, M.L., Violle, C., ... Roumet, C. (2017). Climate, soil and plant functional types as drivers of global fine-root trait variation. Journal of Ecology, 105 (5), 1182-1196. https://doi. org/10.1111/1365-2745.12769

Freschet, G.T., Violle, C., Bourget, M.Y., SchererLorenzen, M., \& Fort, F. (2018) Allocation, morphology, physiology, architecture: themultiple facets of plant above- and below-ground responses to resource stress. New Phytologist, 219 (4), 13381352. https://doi.org/10.1111/nph.15225

Li, F.L., McCormack, M.L., Liu, X., Hu, H., Feng, D.F., \& Bao, W.K. (2020). Vertical fine-root distributions in five subalpine forest types shifts with soil properties across environmental gradients. Plant and Soil, 456, (1-2), 1-15. https://doi:10.1007/ s11104-020-04706-x

Lozanova, L., Zhiyanski, M., Vanguelova, E., Doncheva, S., Marinov, M., \& Lazarova, S. (2019). Dynamics and Vertical Distribution of Roots in European Beech Forests and Douglas Fir Plantations in Bulgaria. Forests, 10 (12), 1123. https:// doi:10.3390/f10121123

Püttsepp, Ü., Lõhmus, K., Persson, H. A., \& Ahlström, K. (2006). Fine-root distribution and morphology in an acidic Norway spruce (Picea abies (L.) Karst.) stand in SW Sweden in relation to granulated wood ash application. Forest Ecology and Management, 221 (1-3), 291-298. https:// doi:10.1016/j.foreco.2005.10.012

Schmid, I. (2002). The influence of soil type and interspecific competition on the fine root system of Norway spruce and European beech. Basic and Applied Ecology, 3 (4), 339-346. https:// doi:10.1078/1439-1791-00116

Schmid, I., \& Kazda, M. (2002). Root distribution of Norway spruce in monospecific and mixed stands on different soils. Forest Ecology and Management, 159 (1-2), 37-47. https://doi:10.1016/s03781127(01)00708-3

Schuurman, J.J., \& Goedewaagen, M.A.J. (1971). Methods for the Examination of Root Systems 
and Roots. Wageningen: Centre for Agricultural Publishing and Documentation.

\section{Peculiarities of soil root population in spruce forests in the area of the mountain tourist network}

\author{
V. Yukhnovskyi', Yu. Ivanenko², \\ G. Lobchenko ${ }^{3}$
}

The role and features of the European spruce root systems structure in the conditions of recreational load in the tourist routes area of the Carpathian National Nature Park (NNP) are described. The aim of the study is to establish the ratio of the volume and surface area that interacts with the soil for conductive and physiologically active roots as a prerequisite for anti-erosion resistance of spruce phytocenoses under recreational load conditions.

To determine the silvicultural and biometric indicators of tree species at the forest stand 13 circular and semicircular temporary trial areas were laid down according to the method which had become well established and commonly usedin forest measurement and forest management. The studied plantations are mostly pure in composition, less often mixed with the predominance of European spruce and 1-2 units' participation in the forest composition by beech (Fagus sylvatica L). or single specimens of the genus Salix L. The age structure is dominated by medieval and premature stands.

The root systems are the main anti-erosion element of forest phytocenosis on sloping lands, where the leading (skeletal) roots provide consolidation of trees in a vertical position, and physiologically active provides soil consolidation, participates in the formation of waterproof aggregates, improving soil permeability and activation of soil-forming processes. An important indicator of the roots involvement in

Vasyl Yukhnovskyi - full Member of the Forest Academy of Sciences of Ukraine, Doctor of Agricultural Sciences, Professor of the department of forests restoration and forest meliorations. National University of Life and Environmental Sciences of Ukraine, General Rodimtsev str., 19, Kyiv, 03041, Ukraine. Tel. + 38-067-720-32-16. E-mail: yukhnov@ukr.net ORCID: http://orcid.org/0000-00033182-4347

Yurii Ivanenko - postgraduate student of the Department of forests restoration and forest meliorations. National University of Life and Environmental Sciences of Ukraine, General Rodimtsev str., 19, Kyiv, 03041, Ukraine. Tel.: + 38-063-870-88-10. E-mail: ura1408280594@gmail.com ORCID: https://orcid.org/00000002-3530-9206

Ganna Lobchenko - Candidate of Agricultural Sciences (PhD), Associate Professor of the Department of Forests Restoration and Forest Meliorations. National University of Life and Environmental Sciences of Ukraine, General Rodimtsev str., 19, Kyiv, 03041, Ukraine. Tel.: + 38-097-885-30-39. E-mail: lobchenko@nubip. edu.ua ORCID: https://orcid.org/0000-0001-9281-1107 the landscapes erosion resistance increasing is their volume and surface area, which interacts with the soil solution.

The main role in the absorption of nutrients by the underground part of the tree is played by physiologically active roots. There is a natural competition between the root systems in both pure and mixed stands. A denser interweaving of root systems is observed on nutrient-rich soils. However, the high density of root systems is due to the water limit on limited access to nutrients. The plasticity of the physiological root, its biomass and the density of distribution indicate the level of ability to compete for habitat.

136 samples of root-containing soil layer at a depth of $0-10 \mathrm{~cm}, 10-20,20-30$ and $30-40 \mathrm{~cm}$ were taken from the sample areas of stands growing in clean and with a small participation of medieval beech forest and ripening stands, from which the roots of European spruce were isolated from division into conductive and physiologically active roots. Also volumes and surface areas of these roots have been calculated.

Statistical correlations between altitude and the volume of the fraction of physiologically active and conductive roots were established, the correlation coefficients of which are 0.78 and 0.47 , respectively. The distribution of the root systems of European spruce depending on the depth of the parent rock showed that in the upper mineral layers of the soil by volume the fraction of the leading root predominates.

In some cases, its volume increases with depth, which affects the density of the conductive root. The surface area of the roots is dominated by physiologically active roots at a depth of $0-20 \mathrm{~cm}$, while at a depth of 20-30 there is a predominance of the leading root. In plantations with stronger soil profiles (over $30 \mathrm{~cm}$ ) in the upper layers $(0-20 \mathrm{~cm})$ and at a depth of $30-40 \mathrm{~cm}$ the fraction of the leading root predominates, but at a depth of $20-30 \mathrm{~cm}$ this tendency changes in favor of physiologically active roots. The main part of the roots is located in the upper mineral layer of the soil at a depth of up to $10 \mathrm{~cm}$ on the objects of nature reserves, which are more sensitive to recreational loads in the mountain conditions. In this soil horizon the share of conducting and physiological roots of the total volume of each fraction is 67.5 and $75.3 \%$, and in places with rock outcrops -72.7 and $87.5 \%$, respectively.

Key words: Carpathian National Natural Park; European spruce; root systems; conductive roots; physiologically active roots. 


\section{Особенности корненаселенности почвы в еловых древостоях в зоне горной туристической сети}

\author{
В.Ю. Юхновский ${ }^{1}$ Ю.С. Иваненко², \\ А. А. Лобченко
}

Изучены особенности корненаселенности почвы под насаждениями ели европейской в условиях рекреационной нагрузки в зоне туристических маршрутов Карпатского национального природного парка. На 13 пробных площадях, заложенных в чистых и с небольшим участием бука лесного средневозрастных и приспевающих насаждениях, отобрано 136 образцов в корнеобитаемом слое почвы на глубине $0-10,10-20,20-30$ и 30-40 см. Из отобранных образцов выделены корни ели

Юхновский Василий Юрьевич - академик Лесной академии наук Украины, доктор сельскохозяйственных наук, профессор кафедры возобновления лесов и лесных мелиораций. Национальный университет биоресурсов и природопользования Украины, ул. генерала Родимцева, 19, г. Киев, 03041, Украина. Тел.: +38-067-720-32-16. E-mail: yukhnov@ukr.net ORCID: http://orcid.org/0000-0003-3182-4347

2 Иваненко Юрий Сергеевич - аспирант кафедры воспроизводства лесов и лесных мелиораций. Национальный университет биоресурсов и природопользования Украины, ул. Генерала Родимцева, 19, г. Киев, 03041, Украина. Тел .: + 38-063-870-8810. E-mail: ura1408280594@gmail.com ORCID: https://orcid. org/0000-0002-3530-9206

Лобченко Анна Александровна - кандидат сельскохозяйственных наук, доцент кафедры воспроизводства лесов и лесных мелиораций. Национальный университет биоресурсов и природопользования Украины, ул. Генерала Родимцева, 19, г. Киев, 03041, Украина. тел .: +38-097-885-30-39. E-mail: lobchenko@nubip.edu.ua ORCID: https://orcid.org/0000-00019281-1107 европейской с последующим разделением на проводящие и физиологически активные с последующим вычислением объемов и площадей поверхности этих корней. Установлены статистические связи между высотой над уровнем моря и объемом фракции физиологически активных и проводящих корней, коэффициенты корреляции которых составляют 0,78 и 0,47 соответственно. Распределение корней ели европейской в зависимости от глубины залегания материнской породы показало, что в верхних минеральных слоях почвы по объему преобладает фракция проводящих корней. В некоторых случаях ее объем возрастает с глубиной, что влияет на плотность распространения проводящих корней. По площади поверхности преобладают физиологически активные корни на глубине 0-20 см, в то время, как на глубине 20-30 см наблюдается преобладание проводящих корней. В насаждениях с более мощными грунтовыми профилями (более $30 \mathrm{~cm}$ ) в верхних слоях (0-20 см) и на глубине 30-40 см преобладает фракция проводящих корней, но на глубине 20-30 см эта тенденция меняется в пользу физиологически активных корней.

На объектах природно-заповедного фонда основная часть корней находится в верхнем минеральном слое почвы на глубине до 10 см, вследствие чего ель становится очень чувствительной к рекреационным нагрузкам в горных условиях. В этом горизонте почвы участие проводящих и физиологически активных корней от общего объема каждой фракции составляет 67,5 и $75,3 \%$, а в местах с выходами горных пород - 72,7 и $87,5 \%$ соответственно.

Ключевые слова: Карпатский национальный природный парк; ель европейская; корневые системы; проводящие корни; физиологически активные корни. 